\title{
CHARACTERISTICS OF SWIFT FOX DENS IN NORTHWEST TEXAS
}

\author{
Brady K. McGee ${ }^{1}$, Kerry L. Nicholson ${ }^{1}$, \\ Warren B. Ballard ${ }^{1,2}$, and Matthew J. Butler ${ }^{1}$
}

\begin{abstract}
The swift fox (Vulpes velox) was classified in 1995 as a candidate for listing under the Endangered Species Act. Since then, several studies have addressed survey methods for monitoring swift fox populations. The purpose of this paper is to assist field researchers in documenting the presence of swift foxes by identification of recently active den sites. We propose that swift foxes have unique external den characteristics that can be distinguished during aerial surveys. We collected data from 30 swift fox den complexes on both continuous rangeland and landscapes fragmented by cropland in northwest Texas. There were no differences in den characteristics between landscape types $(P>$ 0.10). The number of openings per den ranged from 1 to 8 and had an average opening height of $20 \mathrm{~cm}$. As number of openings increased, the maximum distance between openings also increased $(r=0.88, P<0.001)$. One of the most distinguishing characteristics of swift fox dens was their dirt tailing. Of 74 den openings examined, all but 3 had conspicuous dirt tailings that averaged $267.0 \mathrm{~cm}$ long by $63.4 \mathrm{~cm}$ wide. We found that swift fox den openings were smaller than those of coyotes (Canis latrans) and red foxes (Vulpes vulpes), 2 species that can be sympatric with swift foxes. We suggest that aerial den searching followed by ground verification may be an effective technique for determining presence of swift foxes in areas of short-grass prairies and fragmented habitats.
\end{abstract}

Key words: aerial survey, dens, den characteristics, den sites, swift fox, Texas, Vulpes velox.

Swift foxes (Vulpes velox) were once abundant throughout the short-grass and mid-grass prairies of North America but have declined with European settlement (Egoscue 1979). Populations were reduced by habitat destruction and the indiscriminate use of traps and poison baits to control large carnivores, principally wolves (Canis lupus) and coyotes (Canis latrans; Bekoff 1977, Hines 1980, Scott-Brown et al. 1987). Swift fox populations began to increase by the mid-20th century but still remain below historic levels (Egoscue 1979, Samuel and Nelson 1982). In 1992, the United States Fish and Wildlife Service (USFWS) was petitioned to list the swift fox as Threatened under the Federal Endangered Species Act (Cotterill 1997, Allardyce and Sovada 2003). In 1995 the USFWS concluded that listing was warranted but precluded by higher priorities (USFWS 1995, Allardyce and Sovada 2003). Following a widespread conservation initiative by state and federal wildlife agencies, the USFWS removed the swift fox from the candidate species list in January 2001 (USFWS 2001, Allardyce and Sovada 2003). Despite this improved listing status, state agencies are committed to monitoring populations (Allardyce and Sovada 2003).
Swift foxes are secretive, nocturnal animals, and their presence is difficult to document. Several studies have evaluated survey methods for monitoring swift fox populations (Harrison et al. 2002, Schauster et al. 2002, Olson et al. 2003, Sargeant et al. 2003, Shaughnessy 2003). No evaluation of den surveys to monitor presence of swift foxes has been conducted. Swift foxes use dens year-round (Egoscue 1979). If swift fox dens can be distinguished from dens of other species and if they can be efficiently detected, then den surveys might be a useful tool for monitoring swift fox distribution.

Den ecology of swift foxes has been described in several studies (Cutter 1958, Kilgore 1969, Uresk and Sharps 1986, Pruss 1999, Jackson and Choate 2000, Harrison and Whitaker-Hoagland 2003). Researchers have mainly reported on habitat characteristics of den sites such as topography, vegetation, soils, land use, water, and proximity to human disturbance (Harrison and Whitaker-Hoagland 2003). Jackson and Choate (2000) compared physical characteristics of swift fox dens between rangeland and cropland, but little detail was given to dimensions of dirt tailings. They categorized den tailings as not present, approximately the

\footnotetext{
${ }^{1}$ Department of Range, Wildlife, and Fisheries Management, Texas Tech University, Box 42125, Lubbock, TX 79409.

${ }^{2}$ Corresponding author.
} 
same size as the den opening, or at least twice as large as the den opening; den opening dimensions were provided. They found that most den features were not different between habitat types, but there were more dens in croplands with no tailings.

Our objectives were to assist field researchers in documenting the presence of swift foxes by reporting den site characteristics that may be used to identify swift fox dens during aerial surveys (Sargeant et al. 1975). For this study, we ascertained differences in den characteristics between a continuous rangeland and a fragmented landscape to determine whether swift fox dens could be identified across landscapes. Agricultural landscapes may limit suitable swift fox den sites, resulting in different den characteristics than those in rangeland. We also report whether swift fox dens could be observed during an aerial survey.

\section{StUdy AREA}

We studied swift fox dens at two $100-\mathrm{km}^{2}$ study sites in northwest Texas. The first study site (hereafter PR) was on a private ranch located on the border of Dallam and Sherman Counties, approximately $12 \mathrm{~km}$ south of Stratford, Texas $\left(36^{\circ} 24^{\prime} \mathrm{N}, 102^{\circ} 19^{\prime} \mathrm{W}\right)$. This area consisted of rangelands (35\%), cultivated fields (30\%), and Conservation Reserve Program (CRP) lands (35\%). Rangelands consisted of short-grass prairie dominated by blue grama (Bouteloua gracilis) and buffalo grass (Buchloe dactyloides) that was moderately to intensively grazed by cattle (Bos taurus). Cultivated fields were largely corn (Zea mays) or winter wheat (Triticum aestivum) and irrigated by center pivots. Most of the CRP lands were planted with warm-season grasses, including Old World bluestem (Bothriochloa ischaemum), sideoats grama (Bouteloua curtipendula), blue grama, sand dropseed (Sporobolus cryptandrus), and buffalo grass.

The second study site (hereafter NG) included parts of the Rita Blanca National Grassland and privately owned rangeland in Dallam County approximately $55 \mathrm{~km}$ west of Stratford, Texas $\left(36^{\circ} 31^{\prime} \mathrm{N}, 102^{\circ} 64^{\prime} \mathrm{W}\right)$. The NG study site consisted only of rangelands similar to those at the PR study site: short-grass prairie dominated by blue grama and buffalo grass. The area was also moderately to intensively grazed by cattle.

\section{METHODS}

We captured, handled, and radio-collared swift foxes using methods described by Kamler et al. (2002). We located diurnal resting sites (den complexes) of swift foxes with a handheld antenna 1-2 times per week. Because our objective was to assist field researchers in identifying swift fox dens in any season, we took measurements each time a single fox or adult pair was radio-tracked to a new den complex in all seasons. We measured 15 active dens from each study site. Refurbished dens apparently dug by other species were noted.

We collected the following data at each den: number of den entrances, shape of each entrance (round, oval, keyhole), entrance size (height), tailing length, tailing width (measured at length midpoint), maximum distance between entrances, and minimum distance between entrances. Shape of each den entrance was classified according to methods of Jackson and Choate (2000). Tailing refers to the excavated dirt kicked outward from den entrances in a "tail" shape (Kilgore 1969, Jackson and Choate 2000). Maximum and minimum distances between den openings were only recorded from den complexes with $\geq 2$ openings. All measurements were made to the nearest centimeter. We also noted whether dens had identifiable tracks and if they were littered with scats, bones, feathers, or other evidence of activity.

For aerial den detection, we chose a continuous 1000-ha area on the PR study site where we had radio-tracked 4 adult swift foxes to their dens once a week for the previous 8 months. These 4 swift foxes were the only adults captured in this 1000-ha area in the previous 8 months. Because our primary objective was to determine if swift fox dens could be observed from an airplane, we were not concerned with pseudosampling. During September 2004 we flew 2 systematic strip-transect surveys at 160 $\mathrm{km} \cdot \mathrm{hr}^{-1}$ in a Cessna 173 (Cessna Aircraft Company, Wichita, Kansas) fixed-wing airplane (Sargeant et al. 1975). The pilot and 2 observers were familiar with den characteristics but unfamiliar with the known den locations. They conducted both aerial surveys over the same area. The 1st survey was flown at $100 \mathrm{~m}$ above ground level (AGL), whereas the 2nd was 150 $m$ AGL immediately following the first. Transects for the 2nd survey were flown in opposite directions from the 1st so observers were 
not searching the same area and recounting dens they might have already noted. Transect centerlines were spaced at 400-m intervals and oriented east to west. For $100 \%$ transect coverage, the 2 observers each searched a 200-m swath on their side of the transect centerline. We used a Garmin global positioning system (GPS) receiver (Garmin International, Inc., Olathe, Kansas) to navigate along transects and record observed den locations. We rated observed dens on a scale of $1-5$; a rating of 1 meant the observer was not confident the den was used by a swift fox, and 5 meant the observer was sure the observed burrow was a swift fox den. Only dens with ratings $\geq 2$ were used in the analysis. Dens observed during aerial surveys were referenced to GPS coordinates of known den locations.

\section{Statistical ANALYsis}

Our sample sizes were small, and data distributions for the 2 study sites were nonnormal; thus we used Mann-Whitney nonparametric tests to compare the number of den openings and the maximum and minimum distance between openings (Zar 1999). Differences between study sites for mean entrance size, tailing length, and tailing width were calculated with $t$ tests (Zar 1999). A 2-independent-samples proportion test was used to compare entrance shape (i.e., round, oval, or keyhole) between study sites (Zar 1999). Correlation and regression analyses were performed for number of openings versus maximum distance between openings, number of openings versus minimum distance between openings, and tailing length versus tailing width. Differences were deemed significant when $P<0.05$.

\section{Results}

We captured and radio-tracked 29 swift foxes on NG and 26 on PR. Thirty dens belonging to 55 swift foxes were examined throughout the year from January 2002 to May 2003. All 30 dens were littered with swift fox scats and found in rangeland habitat. Only 1 swift fox den appeared to have been originally dug by a badger (Taxidea taxus). Also, $27 \%$ were littered with small bones and bird feathers. On 2 occasions kangaroo rats (Dipodomys ordii) were cached near den openings. Tracks were present at all dens, but no tracks were identifiable to species due to soft soil and high winds.
We found no differences between study sites for any of the den characteristics measured $(P$ $>0.10)$. Therefore, we combined data from both study sites. The number of openings (mean $\pm s_{\bar{x}}$ ) for all swift fox dens measured $(n$ $=30$ ) was $2.5 \pm 1.8$ (range $1-8$ ). Only 2 types of entrance shapes were documented at both study sites. Of the 74 den openings, $89.0 \%$ were round and $11.0 \%$ were oval. Den opening height averaged $20.3 \pm 2.6 \mathrm{~cm}$ (range 16-17 $\mathrm{cm}, n=$ 74). Mean tailing length was $267.0 \pm 109.0 \mathrm{~cm}$ (range 76-549 $\mathrm{cm}, n=72$ ). Three entrances had no tailings, while 1 entrance had 2 tailings. Mean tailing width was $63.4 \pm 16.5 \mathrm{~cm}$ (range 28-102 cm, $n=72$ ). Mean maximum distance between den openings within a den complex was $584.7 \pm 256.9 \mathrm{~cm}$ (range 194-1084 $\mathrm{cm}, n=16$ ). Mean minimum distance between den openings was $228.3 \pm 120.1 \mathrm{~cm}$ (range 87$493 \mathrm{~cm}, n=16$ ).

There was a positive correlation $(r=0.88$, $P<0.001)$ between number of den openings and maximum distance between openings. Regression analysis indicated that $78.2 \%$ of variability in maximum distance between entrances was due to the number of entrances per den $(F=50.12, P<0.0001)$. In contrast, there was a negative correlation $(r=-0.71, P$ $=0.002$ ) between number of den openings and minimum distance between openings. Number of den openings explained $50 \%$ of the variation in minimum distance between openings $(F=14.00, P=0.002)$. Also, there was a positive correlation between tailing length and tailing width $(r=0.64, P<0.001)$.

We tracked 4 adult swift foxes $(2$ mated pairs) to 26 separate dens within the 1000-ha area on the PR during an 8-month period prior to our aerial den survey. During the 100$m$ AGL aerial survey, 6 dens with a rating $\geq 2$ were observed. They constituted $23.1 \%$ of the 26 known swift fox dens. During the $150 \mathrm{~m}$ AGL survey, 7 dens with a rating $\geq 2$ were observed (26.9\% of known dens).

\section{Discussion}

Our mean den-opening height of $20.3 \mathrm{~cm}$ is consistent with averages $(19.0 \mathrm{~cm}$ wide by $21.6 \mathrm{~cm}$ high) from other studies (Cutter 1958, Hillman and Sharps 1978, Pruss 1999, Jackson and Choate 2000). We suspect that narrow entrance height at swift fox dens is a means of predator avoidance. Kilgore (1969) suggested 
that entrances to swift fox dens are too narrow to accommodate predators such as coyotes. Similarly, White et al. (1994) suggested that kit foxes (Vulpes macrotis) were able to survive in coyote home ranges by establishing a number of dens $(\geq 20)$ to facilitate escape. Thus, swift fox den openings seem to be small enough to exclude larger predators such as coyotes. Coyote dens are usually about $30 \mathrm{~cm}$ in diameter (Bekoff 1977, Althoff 1980, Bekoff 1982) but may be as large as $37 \mathrm{~cm}$ (Harrison and Gilbert 1985).

Shape of swift fox den openings did not differ between our 2 study sites. Almost $90 \%$ of all den openings were round while the remaining were oval. In contrast, Jackson and Choate (2000) found most openings to be either oval or keyhole-shaped in both rangeland and cropland study areas. We suspect that openings of dens originally excavated by swift fox would be round. Older dens exposed to weathering, dens in soft soil types, and those excavated by other animals may have various shapes such as oval, keyhole, or dome. For example, we tracked 3 separate adult swift fox on 3 different occasions to a den on NG that was oval in shape and apparently originally excavated by a badger. The den had a single opening $26 \mathrm{~cm}$ tall with an old, crescent-shaped mound of dirt in front, which was similar to badger dens reported by Sargeant and Warner (1972). We presume that the swift foxes had further excavated the den because there was a $71-\mathrm{cm}$ dirt tailing extending beyond the crescent-shaped mound.

During our study there was a significant positive correlation between number of swift fox den openings and maximum distance between openings. We have shown that as the number of openings at swift fox dens increased, so did overall size. In contrast, we also found that as dens grew larger in size and more openings were added, the distance between openings grew smaller.

Differences in swift fox den characteristics may be the result of different functions in different seasons (dispersing, breeding, whelping; Cutter 1958, Pruss 1999, Jackson and Choate 2000, Tannerfeldt et al. 2003). During whelping season, swift foxes utilize natal dens with as many as 9 or more entrances (Kilgore 1969, Jackson and Choate 2000). However, during dispersal and breeding periods swift foxes may use temporary or escape dens with only 1 or 2 entrances (Kilgore 1969, Jackson and Choate
2000). During any season dens may be abandoned but external den characteristics may persist, especially in times of drought. Sargeant et al. (1975) noted that during aerial surveys in eastern North Dakota, rearing dens recently used by red foxes could be distinguished from dens of previous years. Because red fox dens from previous years could be identified (Sargeant et al. 1975), swift fox dens may persist for long periods as well. Therefore, field researchers need to be familiar with a variety of swift fox den characteristics if they are to use sightings, either of recent or abandoned dens, as a starting point for verification of swift fox presence.

We found that one of the most distinguishing characteristics of swift fox dens in the shortgrass prairie was the dirt tailings, which may serve as a visual cue to facilitate rapid entrance into dens or prevent easy detection by coyotes from a distance. Of 74 den openings examined, only 3 did not have tailings. These 3 were part of a large den complex consisting of $\geq 3$ openings. There was 1 instance where a den opening had 2 distinct tailings. Other burrowing species tend to pile excavated soil near the den entrance. Harrison and Gilbert (1985) noted that coyote dens had a conspicuous pile of excavated soil at the main entrance. Similarly, most badger dens have a single entrance with a large mound of soil in front, and when occupied, entrances are generally partially plugged with loose soil (Sargeant and Warner 1972).

When searching for swift fox dens, researchers should look for long (76-549-cm) and narrow (28-102-cm) dirt tailings (Fig. 1). Swift fox dens can be simple, with 1 opening, or complex, with up to 8 openings. Kilgore (1969) excavated 2 dens in short-grass pastures. One den had 7 entrances leading to a complex network of tunnels up to $1 \mathrm{~m}$ below ground surface. The other den had 5 entrances to 5 branches leading to a zigzag main tunnel $0.64 \mathrm{~m}$ below ground. Typically openings are $20 \mathrm{~cm}$ high and are mostly round but can vary in shape. We found no significant differences in swift fox den characteristics between continuous rangeland and fragmented landscape, indicating that swift fox dens may be distinguishable across landscape types. However, differences in den characteristics may not have been detected since all dens were found in rangeland habitat, even in the fragmented landscape study site (PR). 


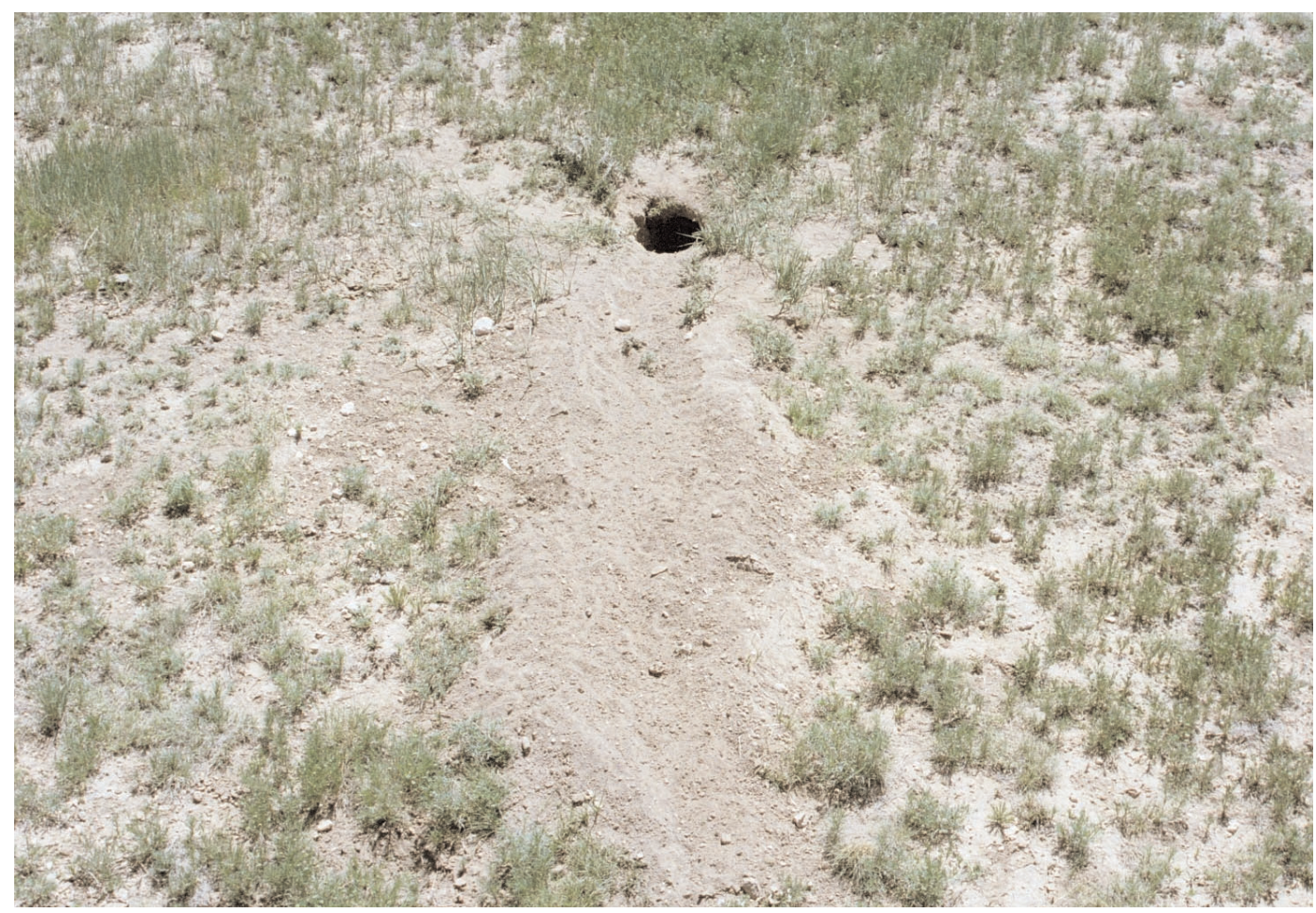

Fig. 1. Photo of a swift fox den entrance on Rita Blanca National Grasslands in 2003 depicting a long dirt tailing.

We suggest that establishing the presence of swift fox dens in an area during aerial surveys may be possible. During the week prior to our aerial survey, it rained $>7 \mathrm{~cm}$ on the study area. The wet ground could have made dens more difficult to see, thereby lowering our counts. However, $26.9 \%$ of known dens that were active during 8 months prior to flying were observed at $150 \mathrm{~m}$ AGL. A detection rate of $26.9 \%$ may be problematic because most dens were undetected. It is possible that there were more dens in the area that we did not know about which would cause our detection rates to be lower. Perhaps surveys for natal dens would be more useful, but only if rate of detection for active dens was near $100 \%$. In any case, ground verification techniques such as live-traps, scent stations (Schauster et al. 2002), or collection of scats for DNA analysis (Harrison et al. 2002) are needed to determine presence of swift foxes after dens with dirt tailings are observed from aircraft. Aerial den searching can be a starting point for researchers trying to cover large areas, but the technique should be developed further if used to monitor swift foxes.
On the other hand, the use of aerial den surveys has been successful with other fox species. Eberhardt et al. (1983) reported surveying arctic fox (Alopex lagopus) dens from the air in flat treeless topography in northern Alaska. Sargeant et al. (1975) observed adult red fox rearing dens during systematic aerial searches in eastern North Dakota. Sargeant et al. (1975) noted that red fox dens were most conspicuous during the early pupping period. We recommend conducting aerial searches for swift fox dens during whelping season when dens with multiple entrances may be more easily identified. We also recommend searching from an altitude of $150 \mathrm{~m}$ AGL. At $100 \mathrm{~m}$ AGL and $160 \mathrm{~km} \cdot \mathrm{hr}^{-1}$, objects on the ground were moving by very rapidly, increasing the difficulty of distinguishing among red harvester ant (Pogonomyrmex barbatus) mounds, prairie dog (Cynomys ludovicianus) holes, and swift fox dens.

In conclusion, we believe that swift fox dens can be easily recognized and distinguished from dens of other medium-sized burrowing animals by their conspicuous den entrance tailings. Sympatric canids and badgers have 
larger den openings and tend to pile excavated dirt near the entrances. Identification and classification of den sites can be a means of making surveys and population estimates more effective (Tannerfeldt et al. 2003), but further research is needed to develop these techniques. Aerial den surveys may be an effective approach to covering large areas but ground verification is needed. Caution should be taken because swift fox presence may be more easily documented than absence. Swift fox dens can be overlooked during aerial surveys.

\section{ACKNOWLEDGMENTS}

Funding was provided by the National Fish and Wildlife Foundation and Texas Tech University. Research protocols were approved by the Animal Care and Use Committee at Texas Tech University. We thank F. Pronger for access to his private ranch and USDA Forest Service personnel for letting us conduct research on the Rita Blanca National Grasslands. We also thank E. Hampton and B. Hampton for providing us with a place to stay while we conducted field research. We thank B. May and G. Burney for their assistance with the aerial den survey. This is Texas Tech University, College of Agricultural Sciences and Natural Resources Technical Publication T-9-997.

\section{Literature Cited}

Allardyce, D., and M.A. Sovada. 2003. A review of the ecology, distribution, and status of swift foxes in the United States. Pages 3-18 in M.A. Sovada and L. Carbyn, editors, The swift fox: ecology and conservation of swift foxes in a changing world. Canadian Plains Research Center, University of Regina, Regina, Saskatchewan, Canada.

Althoff, D.P. 1980. Den and den-site characteristics of coyotes in southeastern Nebraska. Transcripts of Nebraska Academy of Science 8:9-14.

Bekoff, M. 1977. Canis latrans. Mammalian Species 79:1-9. 1982. Coyote Canis latrans. Pages 447-459 in J.A. Chapman and G.A. Feldhamer, editors, Wild mammals of North America: biology, management, and economics. Johns Hopkins University Press, Baltimore, MD.

CotTerill, S.E. 1997. Population census of swift fox (Vulpes velox) in Canada: winter 1996-1997. Alberta Environmental Protection, Natural Resources Service, Wildlife Management Division, Alberta, Canada.

CutTER, W.L. 1958. Denning of the swift fox in northern Texas. Journal of Mammalogy 39:70-74.

Eberhardt, L.E., R.A. Garrott, and W.C. Hanson. 1983. Den use by arctic foxes in northern Alaska. Journal of Mammalogy 64:97-102.

Egoscue, H.F. 1979. Vulpes velox. Mammalian Species 122:1-5.
Harrison, D.J., and J.R. GiLbert. 1985. Denning ecology and movements of coyotes in Maine during pup rearing season. Journal of Mammalogy 66:712-719.

Harrison, R.L., D.J. BarR, and J.W. Dragoo. 2002. A comparison of population survey techniques for swift foxes (Vulpes velox) in New Mexico. American Midland Naturalist 148:320-337.

Harrison, R.L., and J. Whitaker-Hoagland. 2003. A literature review of swift fox habitat and den-site selection. Pages 79-89 in M.A. Sovada and L. Carbyn, editors, The swift fox: ecology and conservation of swift foxes in a changing world. Canadian Plains Research Center, University of Regina, Regina, Saskatchewan, Canada.

Hillman, C.N., AND J.C. Sharps. 1978. Return of swift fox to northern Great Plains. Proceedings of the South Dakota Academy of Science 57:154-162.

Hines, T.D. 1980. An ecological study of Vulpes velox in Nebraska. Master's thesis, University of Nebraska, Lincoln.

JaCkson, V.L., AND J.R. ChOATE. 2000. Dens and den sites of the swift fox, Vulpes velox. Southwestern Naturalist 45:212-220.

Kamler, J.F., W.B. Ballard, R.L. Gilliland, and K. Mote. 2002. Improved trapping methods for swift foxes and sympatric coyotes. Wildlife Society Bulletin 30:12621266.

KILGORE, D.L. 1969. An ecological study of the swift fox (Vulpes velox) in the Oklahoma Panhandle. American Midland Naturalist 81:512-534.

Olson, T.L., J.S. Dieni, F.G. Lindzey, and S.H. ANDERSON. 2003. Swift fox detection probability using tracking plate transects in southeast Wyoming. Pages 93-98 in M.A. Sovada and L. Carbyn, editors, The swift fox: ecology and conservation of swift foxes in a changing world. Canadian Plains Research Center, University of Regina, Regina, Saskatchewan, Canada.

Pruss, S.D. 1999. Selection of natal dens by the swift fox (Vulpes velox) on the Canadian prairies. Canadian Journal of Zoology 77:646-652.

Samuel, D.E., And B.B. Nelson. 1982. Foxes. Pages 475490 in J.A. Chapman and G.A. Feldhamer, editors, Wild mammals of North America: biology, management, and economics. John Hopkins University Press, Baltimore, MD.

Sargeant, A.B., W.K. Pfeifer, and S.H. Allen. 1975. A spring aerial census of red foxes in North Dakota. Journal of Wildlife Management 39:30-39.

SARgEAnT, A.B., AND D.W. WARNER. 1972. Movements and denning habits of a badger. Journal of Mammalogy 53:207-210.

Sargeant, G.A., P.J. White, M.A. Sovada, AND B.L. Cypher. 2003. Scent-station survey techniques for swift and kit foxes. Pages 99-105 in M.A. Sovada and L. Carbyn, editors, The swift fox: ecology and conservation of swift foxes in a changing world. Canadian Plains Research Center, University of Regina, Regina, Saskatchewan, Canada.

Schauster, E.R., E.M. Gese, and A.M. Kitchen. 2002. An evaluation of survey methods for monitoring swift fox abundance. Wildlife Society Bulletin 30: 464-477.

Scott-Brown, J.M., S. Herrero, and J. Reynolds. 1987. Swift fox. Pages 433-441 in M. Novak, J.A. Baker, M.E. Obbard, and B. Malloch, editors, Wild furbearer management and conservation in North America. 
Ontario Ministry of Natural Resources, Ontario, Canada.

Shaughnessy, M.J., JR. 2003. Swift fox detection methods and distribution in the Oklahoma Panhandle. Pages 61-69 in M.A. Sovada and L. Carbyn, editors, The swift fox: ecology and conservation of swift foxes in a changing world. Canadian Plains Research Center, University of Regina, Regina, Saskatchewan, Canada.

Tannerfeldt, M., A. Moehrenschlager, and A. AngerBJORN. 2003. Den ecology of swift, kit and arctic foxes: a review. Pages 167-181 in M.A. Sovada and L. Carbyn, editors, The swift fox: ecology and conservation of swift foxes in a changing world. Canadian Plains Research Center, University of Regina, Regina, Saskatchewan, Canada.

Uresk, D.W., AND J.C. Sharps. 1986. Denning habitat and diet of the swift fox in western South Dakota. Great Basin Naturalist 46:249-253.
USFWS (United States Fish and Wildlife Service). 1995. Endangered and threatened wildlife and plants: 12-month finding for a petition to list the swift fox as endangered. Federal Register 60:31663-31666.

. 2001. Endangered and threatened wildlife and plants: annual notice of findings on recycled petitions. Federal Register 66:1295-1300.

White, P.J., K. Ralls, and R.A. Garrott. 1994. Coyotekit fox interactions as revealed by telemetry. Canadian Journal of Zoology 72:1831-1836.

ZAR, J.H. 1999. Biostatistical analysis. 4th edition. PrenticeHall, Inc., Upper Saddle River, NJ.

Received 12 October 2004 Accepted 3 June 2005 